\title{
Artistic reconstruction of the appearance of Prosantorhinus Heissig, 1974, the teleoceratine rhinoceros from the Middle Miocene of Somosaguas
}

\author{
Marco ANSÓN ${ }^{1,2 *} \&$ Manuel HERNÁNDEZ FERNÁNDEZ2,3
}

\author{
${ }^{1}$ Grupo de Estudio de la Naturaleza AYM, Facultad de Bellas Artes, Universidad Complutense de Madrid, C/ El Greco 2, \\ 28040 Madrid, Spain; paleomarco@yahoo.es \\ ${ }^{2}$ Departamento de Paleontología, Facultad de Ciencias Geológicas, Universidad Complutense de Madrid, C/ Antonio Nováis \\ 2, 28040 Madrid, Spain; hdezfdez@geo.ucm.es \\ ${ }^{3}$ Departamento de Cambio Medioambiental, Instituto de Geociencias (UCM, CSIC), C/ Antonio Nováis 2, 28040 Madrid, \\ Spain \\ * Corresponding author
}

Ansón, M. \& Hernández Fernández, M. 2013. Artistic reconstruction of the appearance of Prosantorhinus Heissig, 1974, the teleoceratine rhinoceros from the Middle Miocene of Somosaguas. [Reconstrucción artística de la apariencia de Prosantorhinus Heissig, 1974, el rinoceronte teleoceratino del Mioceno medio de Somosaguas]. Spanish Journal of Palaeontology, 28 (1), 43-54.

Manuscript received 25 April 2012

Manuscript accepted 25 September 2012

(C) Sociedad Española de Paleontología ISSN 2255-0550

\section{ABSTRACT}

We show the methodology used to perform the artistic palaeoreconstruction of the teleoceratine rhinoceros Prosantorhinus, which is found in the middle Miocene fossil site of Somosaguas-Norte (Pozuelo de Alarcón, middle Aragonian). Successive phases within this work involved (1) the interpretation of the fossils in comparative anatomy terms; (2) the use of modern analogues, considering the systematic relationships among the extinct species and their extant relatives, which allows us to infer the condition of unpreserved attributes such as soft tissues; and (3) addition of palaeoecological information in order to establish the palaeoenvironmental framework of the species. Our finished work shows a plausible reconstruction of the inferred life appearance of Prosantorhinus.

Keywords: Comparative anatomy, Iberian Peninsula, Mammalia, paleoart, Rhinocerotidae.

\section{RESUMEN}

Mostramos la metodología usada para realizar la paleoreconstrucción artística del rinoceronte teleoceratino Prosantorhinus, el cual se encuentra en el yacimiento del Mioceno medio de Somosaguas-Norte (Pozuelo de Alarcón, Aragoniese medio). Las fases sucesivas dentro de este trabajo implicaron (1) la interpretación de los fósiles en términos de anatomía comparada; (2) el uso de análogos modernos, considerando las relaciones sistemáticas entre la especie extinta y sus parientes actuales, lo cual nos permitió inferir la condición de los atributos no preservados tales como tejidos blandos; y (3) la inclusión de información paleoecológica con la finalidad de establecer el contexto paleoambiental de la especie. El resultado final muestra una reconstrucción plausible de la apariencia en vida inferida para Prosantorhinus.

Palabras clave: Anatomía comparada, Península Ibérica, Mammalia, paleoarte, Rhinocerotidae. 


\section{INTRODUCTION}

The Aragonian (middle Miocene) vertebrate fossil sites at the Somosaguas Campus (Pozuelo de Alarcón, Madrid) of the Complutensian University of Madrid have yielded thousands of fossils. Continuous research on these sites has allowed paying special attention to approaches related to public awareness in palaeontology. Particularly, the Somosaguas Paleontology Project is especially interested in the transference of research results on the fauna and environments from central Spain around $14 \mathrm{Ma}$ to the general public. Therefore, it has made a strong outreach activity (Fesharaki et al., 2012), teaching palaeontology to students of different fields (Benítez-López et al., 2009) and spreading the concepts of this discipline to public of all ages (Castilla et al., 2006), including people with different handicaps, in a field called "Social palaeontology" (Torices et al., 2004). For this purpose it is important to summarize research results in order to generate accessible reference images for the general public. In this sense images of the extinct species of the fossil sites can be used as iconic references.

The macrovertebrate fauna from Somosaguas-Norte site includes the rhinoceros Prosantorhinus douvillei, whose remains are the first report of this genus in the Madrid basin (Hernández Fernández et al., 2006). Prosantorhinus is a member of the subtribe Teleoceratina. These distinctive animals conform a very derived group recognized by their short limbs with robust and short metapodials and their barrel-shaped thorax, which gives them a hippo-like appearance in some cases. This abundant and widespread tribe is included in the subfamily Rhinocerotinae (Antoine, 2002). It appeared around $28 \mathrm{Ma}$, in the middle Oligocene of Europe (Diaceratherium) and flourished in the Miocene of Eurasia (Aprotodon, Prosantorhinus, Brachypotherium) arriving North America and Africa, where they got extinct around $2 \mathrm{Ma}$ (Geraads, 2010).

Prosantorhinus was defined by Heissig (1974), who invalided the previously defined genus Brachypodella (Heissig, 1972). This genus is first known from the latest lower Miocene and became extinct at the end of the Aragonian. It includes two species, $P$. germanicus and $P$. douvillei (Heissig, 1972; Prothero et al., 1989; Cerdeño, 1996). The former species was distributed across Germany and France, while the latter one was larger and was present in France, Spain and Portugal. Following Cerdeño (1996), additional unnamed species are known from Buñol (Spain, Prosantorhinus sp. A) and Grive-Saint-Alvan (France, Prosantorhinus sp. B).

While Prosantorhinus is a rhinoceros, it was very different from the modern species of this group. The five living rhinoceroses are included in the subscribe Rhinocerotina, which have a distinctive evolutionary history separated from Teleoceratina at least since the Oligocene (Tougard et al., 2001). This means that the reconstruction of life appearance of Prosantorhinus can be useful as a tool for the public recognition of such evolutionary distinctiveness, from direct comparison with the popular and iconic modern rhinoceros.

When proceeding with the reconstruction of an extinct animal we should follow a sequential work of various steps, from the inner anatomy of the animal to its surface (as summarized in Antón \& Sánchez, 2004). For the reconstruction of the unpreserved attributes we employed the Extant Phylogenetic Bracket approach (Witmer, 1995); this method uses the closest extant relatives to the fossil taxon studied and an additionally basal group as control. By this method we can take phylogenetic inference of attributes based on the distribution of knows features in related taxa (Appendix 1). We have developed the reconstruction of Prosantorhinus in four different phases, from osteological reconstruction, trough analysis of the muscular system and external appearance interpretation, to the inclusion of the animal in its palaeoenvironmental framework.

\section{OSTEOLOGICAL RECONSTRUCTION}

We began our work using the available fossil remains of Prosantorhinus from Somosaguas-Norte as starting point (Hernández Fernández et al., 2006). These include a left hemimandible fragment, which preserves the molar series $\mathrm{m} 1-\mathrm{m} 3$, and has lost the coronoid process and the symphyseal region (SOMN-300). Prosantorhinus has brachyodont dentition, and a robust jaw. There is also a right M3 (SOMN-680) and a right second metacarpal (SOMN-2652), short and robust, which lacks the distal epiphysis and whose proximal epiphysis is broken (Hernández Fernández et al., 2006).

The first step of our work is to assemble the complete skeleton of the species, for which we searched for information from other fossil sites with presence of Prosantorhinus (Cerdeño, 1996) as well as data from other related taxa as Brachypotherium, Diaceratherium and Teleoceras (Prothero, 2005) following the bases of comparative anatomy.

For the reconstruction of the head, first we considered as reference the fossil SOMN-300. We completed the dental series, estimated the position of the symphysis and added the incisors proportionally to the size of the mandible, taking as reference the data from the incisor of $P$. germanicus from Sandelzhausen (Cerdeño, 1996). Our results indicate that the complete jaw should be 45$48 \mathrm{~cm}$ (Fig. 1).

Once the restoration of the jaw was finished, we proceed to estimate the shape of the skull. Due to lack of material, this work relied on the adaptation of the cranial anatomy of Prosantorhinus germanicus according to the proportions of the jaw, taking as a reference the cranial 


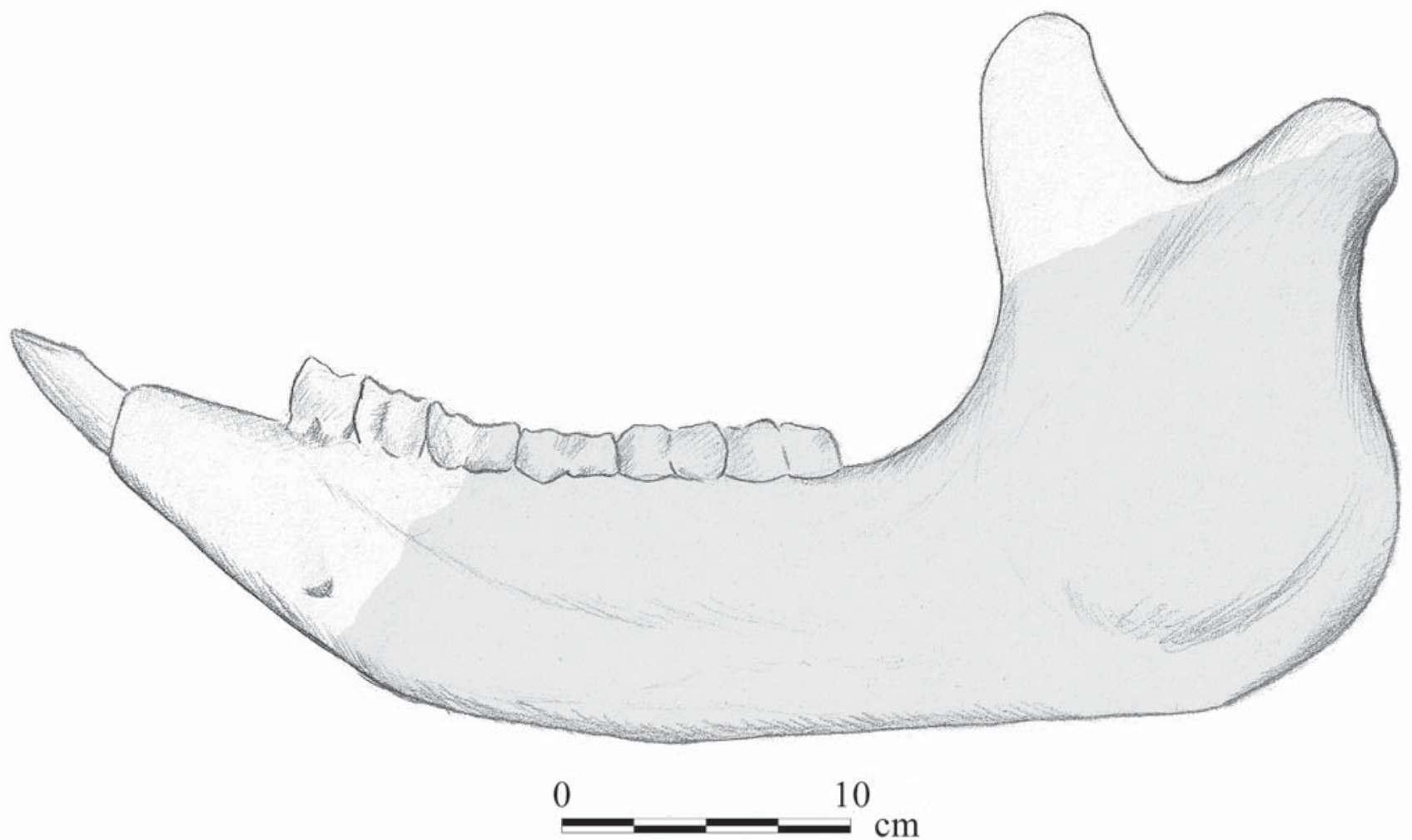

Figure 1. Restoration of the complete jaw SOMN-300 (the grey coloured part is the original fossil) from Somosaguas (artwork by M. Ansón).

descriptions from Cerdeño (1996) and Prothero et al. (1989) and photographies of a skull from Sandelzhausen in exhibition. We conducted a skull scaled by adjusting the proportions by a slight neurocranium elongation. The features of the skull show a thin, long and roughened nasal extremity. This rugged tip could be the basis of one or perhaps two small horns (Cerdeño, 1996; Heissig, 1999). The dorsal profile is slightly concave, with a short sagittal crest and high and narrow zygomatic archs (Fig. 2a).

The rib cage in this tribe was very broad and barrelshaped. We selected a medium thoracic ratio between Brachypotherium and Teleoceras, for which there is information on complete skeletons (Prothero, 2005), and adapted it to the inferred body size of Prosantorhinus derived from the postcranial data from Somosaguas site and the material described by Cerdeño (1996). The considered remains described by Cerdeño (1996) were a right femur $35 \mathrm{~cm}$ long and a humerus $28 \mathrm{~cm}$ long from Baigneux (Ba 2769 and $\mathrm{Ba}$ 6695, respectively). We used these measurements for the appendicular skeletal reconstruction. According to this material, the postcranial skeleton shows the typical brachypodia of the group, with very short but robust limbs. As final result, our reconstruction shows a wide and low thorax with the sternum in a lower position than the distal symphysis of the humerus (Fig. 3a).

\section{MUSCLES AND BODY SHAPE}

After the skeleton was reconstructed and articulated, the next step in the reconstruction of the animal was the interpretation of the muscle attachment points in order to represent the muscles and deduce general body shape and volume. As references for tissue and muscle distribution in relation to the skeleton we used the extant rhinoceros and tapirs as basal control.

Deep muscles were restored on the basis of the morphology of muscle insertion areas comparing Prosantorhinus jaw with the ones of extant rhinoceroses as its closest relatives and tapirs as basal taxa (Fig. 4). The insertion zone of the masseter muscle in SOMN-300 at the lower edges of the jaw is a broad smooth surface for the insertion of a powerful masseter between the zygomatic arch and the jaw. This is more similar to the morphology seen in Ceratotherium simun than to the one in Tapirus terrestris, who has a smaller surface with ridges for the attachment of the masseter as well as a crest in the anterior labial surface of the coronoid process. Extant Dicerorhinus sumatrensis has rough ridges at the posterior border of the jaw too. The masseter muscle provides volume information that helps us to define the outline of the head while the zygomatic arches provide data on the width. Additionally, 

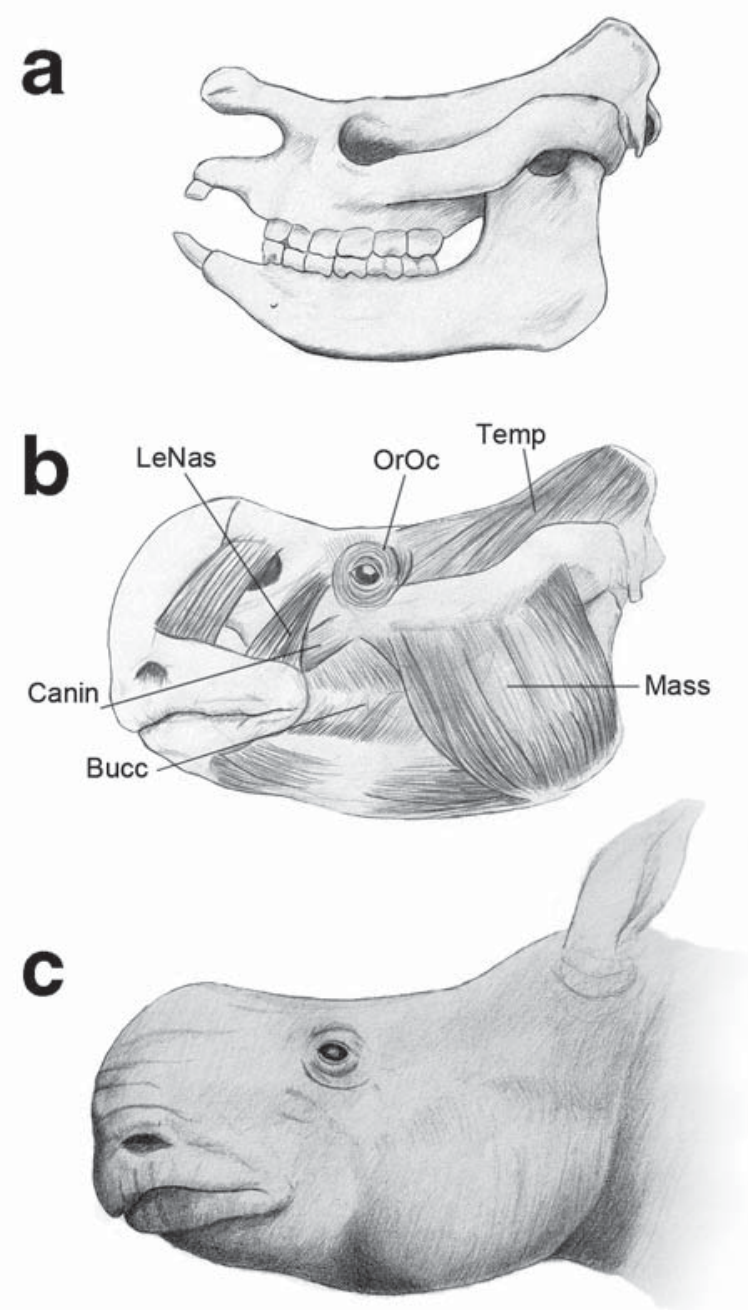

Figure 2. Sequential reconstruction of the head of Prosantorhinus douvillei. a) Skull and mandible. b) Head showing selected muscles (Mass masseter, Temp temporalis, OrOc orbicularis oculi, LeNas levator nasolabialis, Bucc buccinator, Canin caninus). c) Life appearance portrait (artwork by M. Ansón).

in Prosantorhinus the upper edge of the jaw, in which the buccinator muscle is attached, is strong and is placed at the same level than the diastema of the jaw. This situation is similar to the one found in modern rhinoceroses but different to Tapirus, in which the upper edge of the jaw is placed in a higher level than the diastema.

The nasolabial region of Prosantorhinus would extend to the maxillary mesial part, covering incisors and hanging from the extension of the nasal tip (Fig. 2b). Qiu \& Yan (1982) proposed another lip configuration for Chilotherium cornutum, an Aceratheriini rhinoceros with similar proportions in the anterior part of jaw. They proposed a configuration with visible incisors emerging from the lips.
Nevertheless, we have rejected this idea for Prosantorhinus because Chilotherium lower incisors are very strong, long and backward oriented, while Prosantorhinus incisors are smaller and more oriented to the front. This would be similar to the morphology of the extant genus Rhinoceros, in which the lips cover the lower incisors.

The abdominal region appears to be suspended, causing a hippo-like shape for the animal (Fig. 3b). Finally, the limbs are robust, with forelimbs and hindlimbs similar in length and proportion. Prosantorhinus should possess well-developed muscles in order to allow for a proper locomotion supporting its body weight, which has been estimated on $1560 \mathrm{~kg}$ (Perales et al., 2009).

\section{EXTERNAL MORPHOLOGY}

The next step for the reconstruction of the life appearance of an animal is the approach to the skin and other external features that generally are not preserved in fossil record. For example, appearance of the skin is only known on rare occasions of mummified animals or skin impressions (e.g., Chappell et al., 1951). Given this lack of information, we are forced to establish comparisons with extant relatives as a proxy for analogues selection, using the phylogenetic position follow the EPB (Witmer, 1995) and habitats occupied by the species of interest. Taking these considerations into account, we have used the four living rhinoceros genera as analogues for comparison and Tapirus as basal control.

The word rhinoceros describes one peculiarity of these species, the nasal horns, which in popular culture are their diagnostic character. Some Prosantorhinus remains show a couple of rough protuberances in the nasal area, which could suggest the presence of one or two small horns (Cerdeño, 1996; Heissig, 1999), as seen before. The horn is a well developed characteristic in the living species but it was weakly developed in the teleoceratina, being absent in some species. Even though the presence of horns can also be conditioned by factors of sexual dimorphism, well sampled teleoceratine species show no horn dimorphism, ruling out this possibility. In any case, the kind of nasal protuberance present in Prosantorhinus has no modern homologues and may not be an evidence of a horned animal. Therefore, we used both approaches, with and without horns, for the reconstruction of the animal.

It is likely that teleoceratines used their lower incisors like weapons instead of the horns (Fig. 5), using them as daggers in a similar way the living Asian rhinoceroses employ them nowadays (Dinerstein, 2011).

About feeding behaviours, grazing rhinoceroses can be generally distinguished by its hypsodont teeth (Prothero et al., 1989). On the contrary, Prosantorhinus is brachyodont with low non-cemented molars and, therefore, we can tentatively suggest a browser feeding 
a

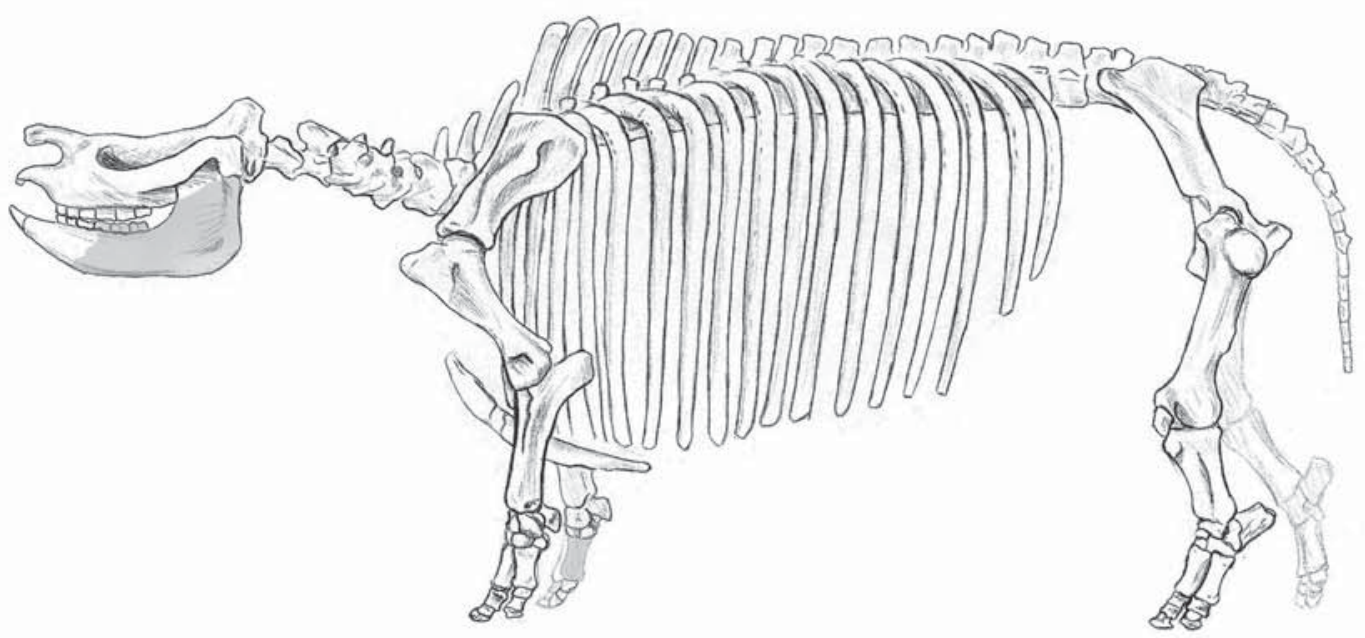

b

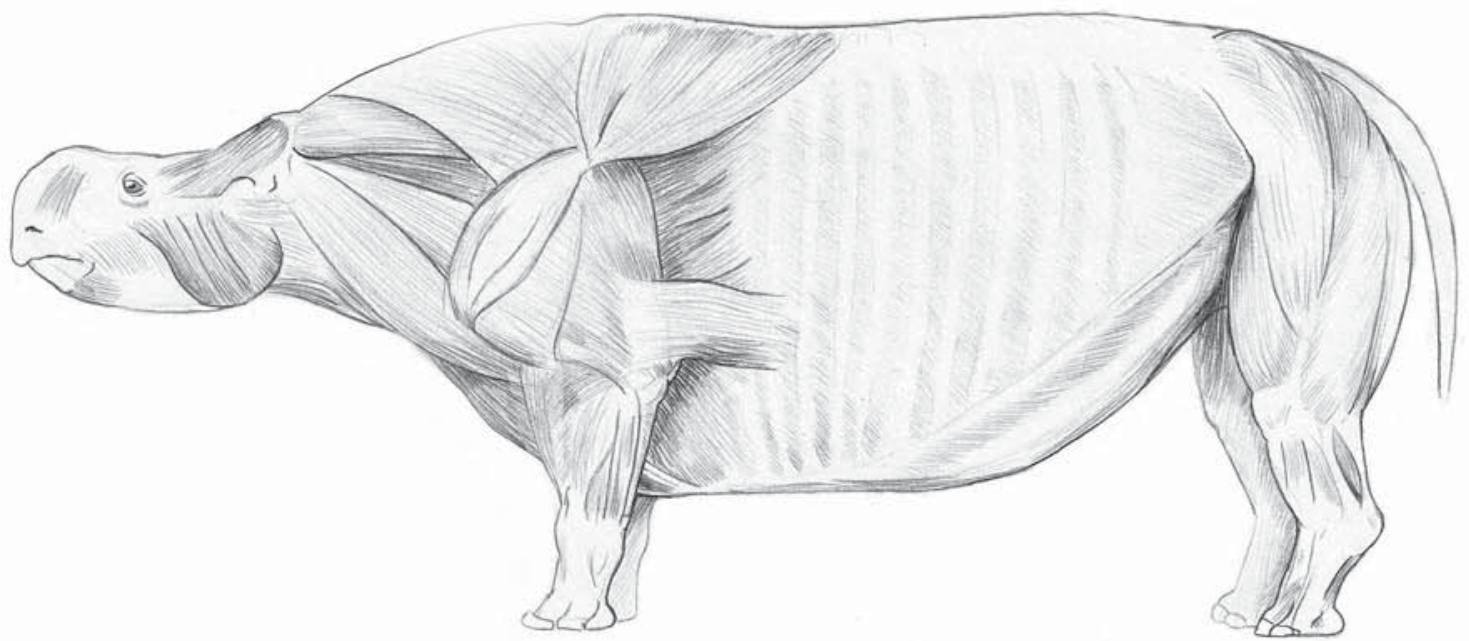

C

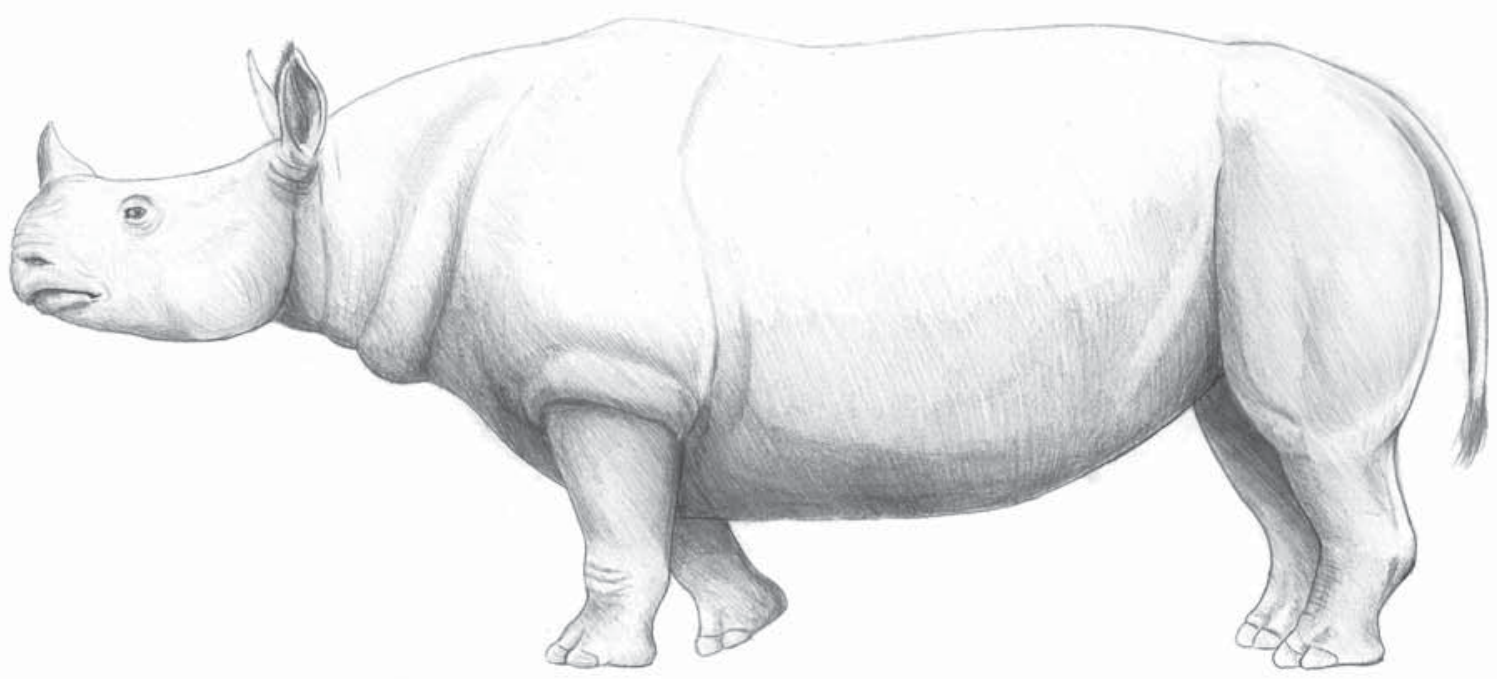

Figure 3. Sequential reconstruction of Prosantorhinus douvillei. a) Skeletal reconstruction (grey parts are the reference material from Somosaguas). b) Reconstructed musculature. c) External appearance (artwork by M. Ansón). 

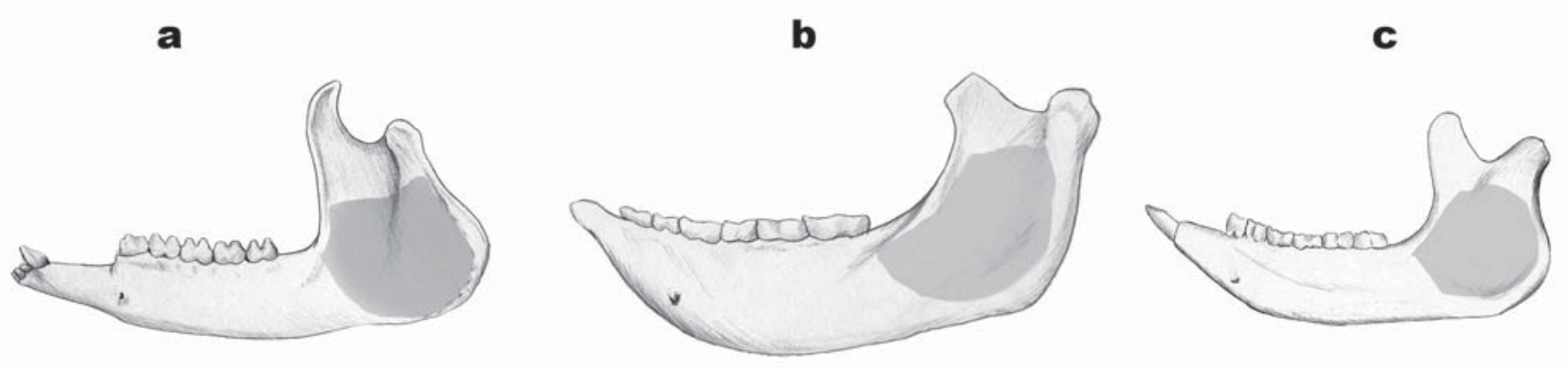

Figure 4. Masseter muscle insertion zones on the jaw of different species. a) Tapirus terrestris. b) Ceratotherium simun. c) Prosatorhinus douvillei. Insertion zones of the masseter muscle are grey coloured (artwork by M. Ansón).

habit (Fortelius, 1982). Isotopic data from material from Somosaguas site confirm that Prosantorhinus may have fed on $\mathrm{C}_{3}$ plants like genus Phragmites (Domingo et al., 2009). Considering the likely supply of wetland vegetation instead of grass (Heissig, 1999) and the labial anatomy of living rhinoceroses more linked to wet environments (Dicerorhinus and Rhinoceros; Dinerstein, 2011), Prosantorhinus is showed with a pointed and prehensile upper lip (Fig. 5). On the other hand, Ceratotherium has a flat upper lip as his own adaptation for grazing habits in grasslands and, therefore, we ruled out the possibility of a flat lip.

Although the location of the ears is linked to the position of the external acoustic pseudomeatus, their size and shape of were based on the living rhinoceroses. Besides, the presence of some hairs on the edge of the ears is inferred in Prosantorhinus, since this feature is present in all the extant rhinoceros species (Fig. 2c).
It is also important to consider the tissue folds, which are finally reflected on the rhinoceros skin at the end of the abdomen zone, between the oblique muscle of the abdomen and the hind limb (Fig. 3b). In this case we relied on the anatomy of African rhinoceroses Ceratotherium simun and Diceros bicornis (Kingdom, 1979). The pronounced armoured skin folds of Rhinoceros seem to be a particular characteristic of this genus and we have avoided them in our reconstruction of Prosantorhinus. Diceros sumatrensis has skin folds with the same distribution that we can see in Rhinoceros but not as developed. Therefore, our reconstruction of the skin appearance of Prosantorhinus shows skin folds in the limbs, trunk and abdomen of the animal, in a similar way to the one found in modern Ceratotherium, Diceros and Dicerorhinus.

For the animal colour patter we have taken into account the trend from more brownish species in closed a

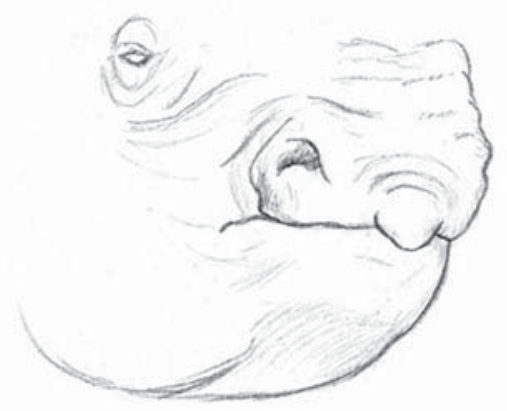

b

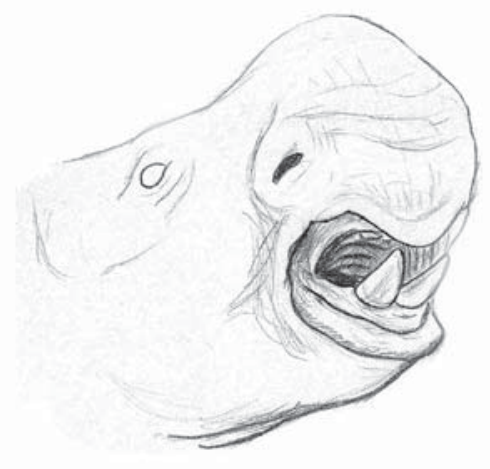

C

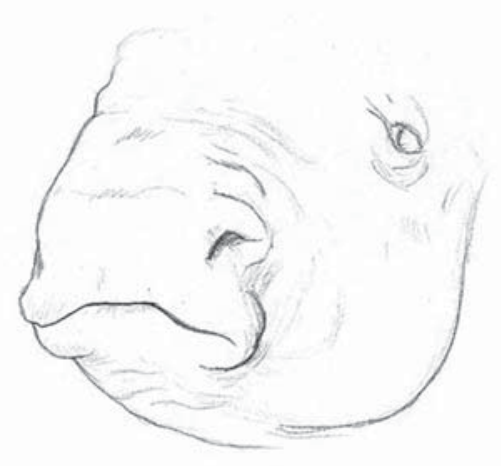

Figure 5. Rhinoceroses lips. a) Diceros bicornis, pointed prehensile lip. b) Prosantorhinus douvillei, pointed lip and mouth showing incisors. c) Ceratotherium simun, flat lip (artwork by M. Ansón). 
environments, as can be observed in the Sumatran rhinoceros, African buffalo and forest elephants, towards a predominance of grey colours in more open landscapes. Therefore, due to the savanna-like environments prevalent in Somosaguas during the Miocene (López-Martínez et al., 2000; Hernández Fernández et al., 2006; Domingo et al., 2009; Perales et al., 2009), we have chosen a grey tone for Prosantorhinus similar to the one observed in three genera of living rhinoceroses, Rhinoceros, Diceros and Ceratotherium.

Extant tapirs have a short hair coat and Dicerorhinus sumatrensis has long hair in some parts of their body. Nevertheless, we rejected a haired reconstruction of Prosantorhinus because it is closer to the extant rhinoceroses than to tapirs. Furthermore, Sumatran rhinoceros is related to the linage of woolly rhinoceros, which had a long hair coat to live in ice ages (Orlando et al., 2003). Maybe the long hair of Sumatran rhinoceros could be a reminiscence of past adaptations for the Quaternary cold environment of Eurasia. Additionally, naked skin is the observed state for large mammals living in hot and warm environments and associated to water and wallow behaviours like hippopotamus, elephants and extant rhinoceroses.

Finally, we have included hairs at the end of the tail, which are present in all living rhinoceroses and other perissodactyls (Fig. 3c).

\section{PUTTING PROSANTORHINUS IN ITS ENVIRONMENTAL CONTEXT}

Once we had completed the life appearance of the animal, the last step was to represent it in its natural habitat. For that purpose we analyzed the data from the palaeontological site of Somosaguas as well as information from the living rhinoceroses in their habitat. Rhinoceroses live in places where a perennial supply of food and water is available. In fact, since they are relatively flexible in their diets, rhinoceroses are strongly dependent upon the presence of the latter. Besides, African species also rely on water for temperature control and on frequent sprays of urine for communication. Additionally, rhinoceroses heavily depend on wallowing in mud, and the wallowing behaviour probably assists temperature control (Kingdon, 1979), something that would be interesting to consider knowing that Somosaguas environment was a semiarid savanna (López-Martínez et al., 2000; Hernández Fernández et al., 2006; Domingo et al., 2009; Perales et al., 2009). Therefore, the final artistic reconstruction of Prosantorhinus in its natural environment shows the animal during the act of wallowing (Fig. 6).

Additionally, morphological similarities between teleoceratines and common hippopotamus lead researchers to think about a semi-amphibious lifestyle and the occupation of wetlands and riverine environments by species of Teleoceratina (Prothero et al., 1989). Hippopotamus-like body proportions have been observed in other groups as the aceratheriines like Chilotherium, posing them as a relatively frequent and successful ecological role in the rhinoceros life-history.

Due to the swampy environment to which Prosantorhinus has been associated, soft aquatic vegetation could become their main food, and this taxon probably included a certain quantity of reed grasses in its diet (Heissig, 1999; Domingo et al., 2009). As seen before, this is corroborated by its brachyodont teeth, unlike other teleoceratine lineages like Teleoceras and Brachypotherium characterized by relatively hypsodont teeth (Prothero et al., 1989; Prothero, 2005).

Finally, Prothero \& Sereno (1982) suggested that dwarf rhinoceroses, as the species included in Prosantorhinus, inhabited more forested environments than their bigger counterparts, and were comparable to modern dwarf forms of hippos, elephants and buffalos, which prefer browsing in forested habitats. This hypothesis could relate Prosantorhinus to the closest environments within the general ecosystem of the Somosaguas savannas, as riverine forest patchs and associated wetlands.

\section{CONCLUSIONS}

In summary, the results of the process of reconstruction show a small size rhino, with an elongated barrel-shaped body and short robust legs that slightly resembles the common hippopotamus in its morphology, which is correlated with habitat preference towards rivers and ponds as well as with a heavy dependence on wet environments and water. This life appearance is aesthetically eye-catching because of the shortness of its limbs and the proportion of the skull, which appears to be small in comparison with the body. The muscle insertions observed in Prosantorhinus jaw are more similar to white rhinoceros than to tapirs and we use this contrast to reconstruct the deep muscles of the head. The body size of Prosantorhinus douvillei, estimated weight in approximately $1,500 \mathrm{~kg}$, reports a heavy and robust animal when compared with $D$. sumatrensis, roughly of the same size, but weighting $800 \mathrm{~kg}$ (Fig. 7).

The final art shows Prosantorhinus in wallow environment to reflect the plausible hypothesis that this species was linked to wet environments, and the drought season inferred for the Miocene of Somosaguas (Hernández Fernández et al., 2006) might increase the necessity and the time spent in the wallowing activity (Fig. 6). This work shows this animal as a very characteristic hippo-like rhinoceros that can become an icon for general public.

The production of a general iconography associated to vertebrate palaeontology is becoming more and more 


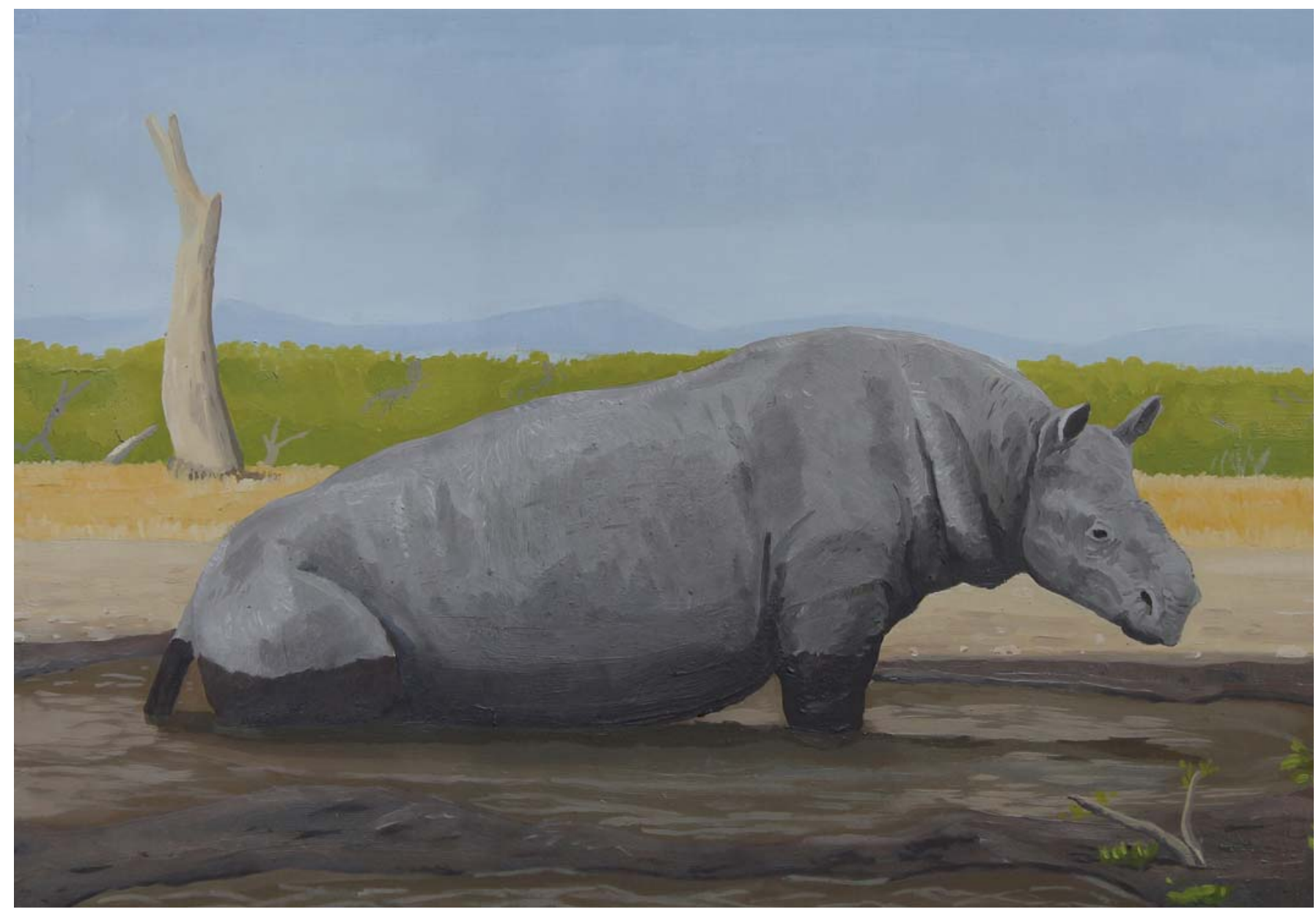

Figure 6. Final reconstruction of Prosantorhinus douvillei in the Somosaguas Miocene landscape (artwork by M. Ansón).

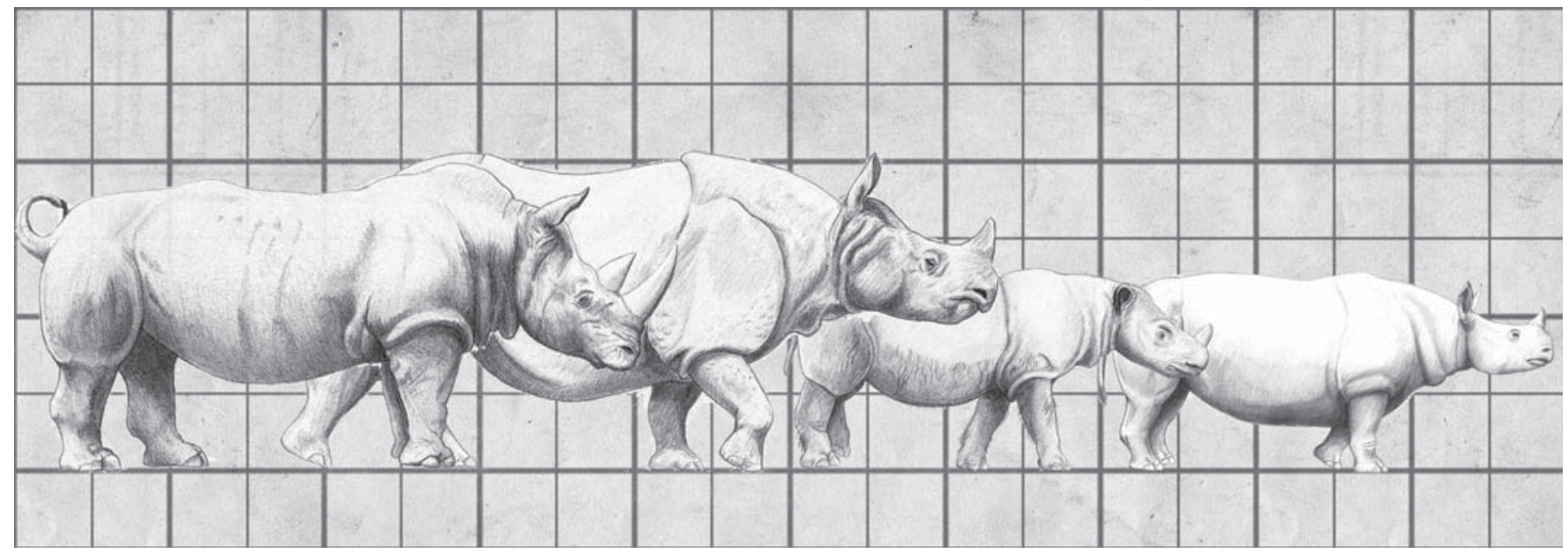

Figure 7. Comparison of Prosantorhinus douvillei with several modern species of rhinoceroses. Left to right: Ceratotherium simun, Rhinoceros unicornis, Dicerorhinus sumatrensis and Prosantorhinus douvillei. Each square measures $50 \mathrm{~cm}$ (artwork by M. Ansón). 
important each day in order to promulgate evolutionary studies to the general public. Therefore, palaeoart will always be an important way to portray animals that no longer exist and expose, show and visually check our ideas about them, and for that purpose we work uniting artistic and scientific disciplines as a multidisciplinary method of study.

\section{ACKNOWLEDGEMENTS}

We gratefully acknowledge to Nieves López Martínez (UCM) her interest in educational innovation, which has allowed acquiring a direct contact with Palaeontology to students not directly related to this discipline. Her work in the Somosaguas Palaeontology Project provided us with the inspiration to make this work. We also want to thank Oscar Sansisidro (MNCN-CSIC), Sergio Pérez González (UCM) and Mauricio Antón (MNCN-CSIC) for their comments, bibliographic recommendations and artistic advice, as well as Laura Soret (UCM) and Alba Vicente (UCM) for their help with the informatics. This is a contribution of the teams of Introduction to GeoPalaeoBiological Research in Somosaguas (EIIGPBS, http://investigacionensomosaguas. blogspot.com.es) and Palaeoclimatology, Macroecology and Macroevolution of Vertebrates (PMMV, http://pmmv. com.es) of the Complutensian University of Madrid. This research has been partially funded by the MICINN (CGL2010-19116/BOS) and the UCM (Research Group UCM-910607 on Cenozoic Mammal Evolution and Continental Palaeoenvironments).

\section{REFERENCES}

Antoine, P.-O. 2002. Phylogénie et évolution des Elasmotheriina (Mammalia, Rhinocerotidae). Publications Scientifiques du Muséum, Mémoires du Muséum national d'Histoire naturelle, 188, 1-359.

Antón, M. \& Sánchez, I.M. 2004. Art and science: the methodology and relevance of the reconstruction of fossil vertebrates. In: Miscelanea en homenaje a Emiliano Aguirre, Paleontología (eds. Baquedano Pérez, E. \& Rubio Jara, S.). Museo Arqueológico Regional, 2, Alcalá de Henares, Madrid, 74-94.

Benítez-López, G., Fesharaki, O., Gómez-Cano, A.R. \& Pérez de los Ríos, M. 2009. Equipo de Introducción a la Investigación GeoPaleoBiológica en Somosaguas: un nuevo enfoque para el aprendizaje de la investigación. Paleolusitana, 1, 105-113.

Castilla, G., Fesharaki, O., Hernández Fernández, M., Montesinos, R., Cuevas, J. \& López-Martínez, N. 2006. Experiencias educativas en el yacimiento paleontológico de Somosaguas (Pozuelo de Alarcón, Madrid). Enseñanzas de la Tierra, 14 (3), 265-270.

Chappell, W.M., Durham, J.W. \& Savage, D.E. 1951. Mold of a rhinoceros in basalt, Lower Grand Coulee, Washington. Bulletin of the Geological Society of America, 62, 907918.

Cerdeño, E. 1996. Prosantorhinus, the small teleoceratine rhinocerotid from the Miocene of Western Europe. Geobios, 29, 111-124.

Dinerstein, E. 2011. Family Rhinocerotidae (rhinoceroses). In: Handbook of the Mammals of the World, Vol. 2: Hoofed Mammals (eds. Wilson, D.E. \& Mittermeier, R.A.). Lynx Editions, Barcelona, 144-181.

Domingo, L., Cuevas-González, J., Grimes, S.T., Hernández Fernández, M. \& López-Martínez, N. 2009. Multiproxy reconstruction of the palaeoclimate and palaeoenvironment of the Middle Miocene Somosaguas site (Madrid, Spain) using herbivore dental enamel. Palaeogeography, Palaeoclimatology, Palaeoecology, 272 (1/2), 53-68.

Fesharaki, O., Torices, A., García Yelo, B.A., Tejedor Navarro, N., de la Ossa, L. \& Hernández Fernández, M. 2012. The Somosaguas Palaeontology Project: an envision of Nieves López Martínez for linking science and society. Spanish Journal of Palaeontology, 27(2), 83-92.

Fortelius, M. 1982. Ecological Aspects of Dental Functional Morphology in the Plio-Pleistocene Rhinoceroses of Europe. In: Teeth, Form, Function, and Evolution (ed. Kurten, B.), Columbia University Press, New York, 163181.

Geraads, D. 2010. Rhinocerotidae. In: Cenozoic Mammals of Africa (eds. Werdelin, L. \& Sanders, W.J.), University of California Press, Berkeley, 669-683.

Heissig, K. 1972. Die obermiozäne Fossil-Lagerstätte Sandelzhausen. 5. Rhinocerotidae (Mammalia), Systematik und Ökoloie. Mitteilungen Bayerische Staatsammlung für Paläontologie und historische Geologie, 12, 57-81.

Heissig, K. 1974. Prosantorhinus PRO Brachypodella HEISSIG, 1972 (Rhinocerotidae, Mammalia) (= non Brachypodella BECK, 1837 [Gastropoda]). Mitteilungen Bayerische Staatsammlung für Paläontologie und historische Geologie, 14, 37.

Heissig, K. 1999. Family Rhinocerotidae. In: The Miocene Land Mammals of Europe (eds. Rössner, G. E. \& Heissig, K.), Munich, Pfeil, 175-188.

Hernández Fernández, M., Cárdaba, J.A., Cuevas González, J., Fesharaki, O., Salesa, M.J., Corrales, B., Domingo, L., Elez, J., López Guerrero, P., Sala-Burgos, N., Morales, J. \& López-Martínez, N. 2006. Los yacimientos de vertebrados del Mioceno medio de Somosaguas (Pozuelo de Alarcón, Madrid): implicaciones paleoambientales y paleoclimáticas. Estudios Geológicos, 62, 263-294.

Kingdon, J. 1979. East African mammals. An atlas of evolution in Africa, Vol. 3. Part B (large mammals), Academic Press, London.

López-Martínez, N., Élez, J., Hernando, J.M., Luis, A., Mazo, A., Mínguez Gandú, D., Morales, J., Polonio, I., Salesa, M.J. \& Sánchez, I. 2000. Los vertebrados 
fósiles de Somosaguas (Pozuelo, Madrid). Coloquios de Paleontología, 51, 69-86.

Orlando, L., Leonard, J.A., Thenot, A., Laudet, V. Guerin, C. \& Hänni, C. 2003. Ancient DNA analysis reveals woolly rhino evolutionary relationships. Molecular Phylogenetics and Evolution, 28 (2), 485-499.

Prothero, D.R. 2005. The Evolution of North American Rhinoceroses. Cambridge University Press, Cambridge.

Prothero, D.R., Guérin, C. \& Manning, E. 1989. The History of Rhinocerotoidea. In: The Evolution of Perissodactyls (eds. Prothero, D. R. \& Schoch, R.M.). Oxford University Press, New York, 321-340.

Prothero D.R. \& Sereno, P.C. 1982. Allometry and paleoecology of medial Miocene dwarf rhinoceroses from the Texas Gulf Coastal Plain. Paleobiology, 8(1), 16-30.

Perales, R., Serrano, H., García Yelo, B. \& Hernández Fernández, M. 2009. Inferencias paleoambientales del Mioceno medio de Somosaguas (Pozuelo de Alarcón,
Madrid) basadas en la estructura de tamaños corporales de su fauna de mamíferos. Paleolusitana, I, 317-325.

Qiu, Z.X. \& Yan, D.F. 1982. A horned Chilotherium skull from Yushe, Shansi. Vertebrata Palasiatica, 20, 122132.

Torices, A., Bolea, B. \& Cuevas, J. 2004. Paleontología Social. Libro de Resúmenes del II Encuentro de Jóvenes Investigadores en Paleontología, Macastre (Valencia), 46-47.

Tougard, C., Delefosse, T., Hänni, C. \& Montgelard, C. 2001. Phylogenetic relationships of the five extant rhinoceros species (Rhinocerotidae, Perissodactyla) based on Mitochondrial Cytochrome b and 12S rRNA genes. Molecular Phylogenetics and Evolution, 19(1), 34-44.

Witmer, L.M. 1995. The extant phylogenetic bracket and the importance of reconstructing soft tissues in fossils. In: Functional Morphology in Vertebrate Paleontology (ed. Thomason, J.). Cambridge University Press, Cambridge, 19-33. 
Appendix 1. Systematic framework for all the taxa mentioned in the text.

Order Perissodactyla OWEN, 1848

Family Tapiridae BURNETT, 1830

Tapirus BRUNNICH, 1772

Tapirus terrestris (LINNAEUS, 1758)

Family Rhinocerotidae GRAY, 1821

Subfamily Rhinocerotinae GRAY, 1821

Tribe Rhinocerotini GRAY, 1821

Subtribe Teleoceratina HAY, 1902

Prosantorhinus HEISSIG, 1972

Prosantorhinus douvillei (OSBORN, 1900),

Prosantorhinus germanicus (WANG, 1928)

Diaceratherium DIETRICH, 1931

Teleoceras HATCHER, 1874

Brachypotherium ROGER, 1904

Aprotodon FORSTER COOPER, 1915

Subtribe Rhinoceratina OWEN, 1845

Rhinoceros LINNAEUS, 1758

Dicerorhinus GLOGER, 1841

Dicerorhinus sumatrensis (FISCHER, 1814)

Diceros GRAY, 1821

Diceros bicornis (LINNAEUS, 1758).

Ceratotherium GRAY, 1867

Ceratotherium simun (BURCHELL, 1817)

Tribe Aceratheriini DOLLO, 1854

Chilotherium RINGSTRÖM, 1924

Chilotherium cornutum (QIU \& YAN, 1982) 
